\title{
Incidence and Level of Mistletoe Infestation in Tree Species at Botswana University of Agriculture and Natural Resources' Sebele Content Farm Campus, Botswana
}

Mogapi E. Madisa ${ }^{1 *}$, Y. Assefa ${ }^{2}$, Omphile D. Kelemoge ${ }^{3}$, Thembinkosi Mathowa ${ }^{4}$, A.T. Segwagwe 5

${ }^{1,3,4,5}$ Department of Crop Science and Production, Botswana University of Agriculture and natural Resources, Private Bag 0027, Gaborone, Botswana

${ }^{2}$ Department of Crop Production, University of Swaziland, Luyengo Campus, P. O. Luyengo M205, Swaziland

\begin{abstract}
A survey was conducted at Botswana University of Agriculture and natural Resources at Sebele content farm to determine the intensity and level of mistletoe infestation in tree species. The intensity and the total number of trees per tree species infected by the parasitic weed were determined. Acacia eriobola, Acacia mellifera, Terminalia sericea, Ziziphus mucronata, Schinus molle, Acacia tortilis, Acacia erubesens and Acacia flekii hosted the highest number of mistletoe. Results revealed significant variation in level of mistletoe infestation between tree species. A $100 \%$ infestation was recorded in some tree species such as Acacia eriobola and Ziziphus mucronata. Severely infested indigenous tree species were dying, whereas most of the exotic tree species were either not infested or have very little number of mistletoe on them. The variation observed could be due to the fact that indigenous species the frequently visited by dispensers looking for food and shelter than exotic species. In addition, there is a possibility that the mistletoe species co-evolved with the indigenous tree species and the vector may be well established on the host tree species than on exotic species.
\end{abstract}

Keywords-Avian-dispersers, Botswana, Infestation, Mistletoe, Tree species.

\section{INTRODUCTION}

Mistletoe is a name originally referring only to the European species Viscum album, but is now used as a general term for woody shoot parasites in several plant families especially Loranthaceae and Viscaceae which belong to the order Santalales. Loranthaceae (Parker and Riches, 1993). There are about 400 species in several genera of Viscaceae, of which at least five can be of economic importance (Barlow, 1993). In Botswana the common mistletoes are Viscum album, Tapinanthus oleifolius, Plicosepalus kalachariensis and Erianthemum ngamicom and all these species are well represented on Botswana University of Agriculture and natural Resources Sebele content farm where this study was conducted.

Mistletoes (excluding Arceuthobium spp.) are leafy and forms spherical, bush like growths reaching as far as $1.0 \mathrm{~m}$ and are particularly eye catching in winter when exposed by the loss of leaves of their host tree (Butin, 1995). The seeds are distributed by birds and germinate if they reach the bark of a suitable host plant, each initially forming a sticky adhesive disc at the tip of the radicle (Parker and Riches, 1993). Most species of Loranthaceae and Viscaceae have sound established photosynthetic capacity from an early stage and should not need to rely on the host as a source of carbon, however, completely dependent on the host for both water and minerals (Liddy, 1993). Mistletoes tend to grow on isolated trees, on the edge of the forest and in the higher branches of the trees (Parker and Riches, 1993;Buen et al., 2002).

Like other parasitic organisms, mistletoes show specialization on host species due to a number of factors. Some mistletoe species are specialized in living on different host due to frequent encounters between mistletoe seeds and commonest plants (Fadini, 2011) and in others, non-random perch preferences of seed dispensers play an important role in determining host specificity (Monteiro et al., 1992). Host tree preference (Fadini, 2011) and host tree height (Rahmad et al., 2014) are also reported to influence the concentration of mistletoe seeds on a host.

It has been observed that several trees species were dying at Botswana University of Agriculture and Natural Resources, Sebele content farm and in different localities across the country because of mistletoe infection. However, there has never been a comprehensive attempt to establish an inventory of the tree host species of mistletoes and the level of mistletoe infestation in the country. The aim of the present study is therefore to establish a baseline inventory of the known host tree species and the level of susceptibility of each host tomistletoes. It is hoped that this paper will stimulate a systematic documentation of the host species of these parasitic plants and the level of susceptibility of each host species to mistletoe infestation. 


\section{MATERIALS AND MeTHODS}

\subsection{The Study area}

The study was conducted at Botswana University of Agriculture and Natural Resources at Sebele content farm campus. The campus is located $24^{\circ} 33^{\prime} \mathrm{S}, 25^{\circ} 54^{\prime} \mathrm{E}$, and $994 \mathrm{~m}$ above sea level (Bekker and De Wit, 1991). The climate in Sebele is semiarid with average rainfall of $538 \mathrm{~mm}$. Most rainfall occurs in summer, which generally starts in the late October and continues to March/April (Persaud et al., 1992). Prolonged dry spell during rainy seasons are common and rainfall tends to be localized.

\subsection{Data collection}

Both exotic and indigenous tree species $(+20 \mathrm{~cm}$ stem diameter and $+3 \mathrm{~m}$ plant height) on campus were identified to their species level and recorded. The abundance of each tree species was determined by counting the number of tree of each species. The number of infested trees for each species was also counted to determine the incidence and infestation percentage of each species. Mistletoe incidence per species was obtained by dividing the proportion of infested trees by the total number of trees of each host species in the campus, and this value was translated into a percentage. The level of infestation per species was determined by calculating the average number of mistletoe plants per tree.

\subsection{Data analysis}

Data collected was subjected to descriptive statistical analysis. Percentage of infested trees was calculated as a proportion of the total number of trees in each species.

\section{RESULTS}

A total of 243trees belonging to 26 species from 15 families of plants were recorded at Botswana University of Agriculture and Natural Resources, Sebele content farm campus (Table 1). Of these 17 species belonging to 10 families were indigenous to Africa and the remaining 9 species belonged to 6 families were exotic. Indigenous trees dominated in abundance as compared to the exotic constituting $72.4 \%$ of the tree stands in the campus. Individual tree species abundance in the campus varied from a minimum of a single tree to a maximum of 37 trees per species with an average 9.3 trees per species.

\section{TABLE 1}

COMMON NAME AND SCIENTIFIC CLASSIFICATION OF THE TREE SPECIES RECORDED IN BOTSWANA UNIVERSITY OF AGRICULTURE AND NATURAL RESOURCES, SEBELE CONTENT FARM CAMPUSDURING THE SURVEY OF MISTLETOE.

\begin{tabular}{|c|c|c|c|}
\hline Common Name & Scientific Name & Family Name & Origin \\
\hline Pepere/California pepper tree & Schinus molle & Anacardiaceae & Exotic \\
\hline Morolwana/China berry & Melia azedarach & Meliaceae & Indigenous \\
\hline Mosetlha & Peltophorum africanum & Caelsapiniaceae & Indigenous \\
\hline Eucalyptus & Eucalyptus globulus & Myrtaceae & Exotic \\
\hline Flamboyant & Delonix regia & Fabaceae & Exotic \\
\hline Mosokaphala & Bolusanthus speciosus & Papilionoideae & Indigenous \\
\hline Tipu tree & Tipuana tipu & Fabaceae & Exotic \\
\hline Morula & Sclerocarya birrea & Anacardiaceae & Indigenous \\
\hline Mongana & Acacia mellifera & Mimosaceae & Indigenous \\
\hline Mogonono & Terminalia sericea & Combretaceae & Indigenous \\
\hline Mohudiri & Combretum apiculantum & Combretaceae & Indigenous \\
\hline Mosu & Acacia tortilis & Mimosaceae & Indigenous \\
\hline Mokgalo & Ziziphus mucronata & Rubiaceae & Indigenous \\
\hline Mothono & Maytenus senegalensis & Celastraceae & Indigenous \\
\hline Motlopi & Boscia albutrunca & Caparaceae & Indigenous \\
\hline Morojwa & Azanza garkeana & Malvaceae & Indigenous \\
\hline Moloto & Acacia erubesens & Mimosaceae & Indigenous \\
\hline Mohahu & Acacia flekii & Mimosaceae & Indigenous \\
\hline Moduba & Combretum zeyheri & Combretaceae & Indigenous \\
\hline Motswiri & Combretum imberbe & Combretaceae & Indigenous \\
\hline Mogotlho & Acacia eriobola & Mimosaceae & Indigenous \\
\hline Brazilian pepper tree & Schinus terebinthifolius & Anacardiaceae & Exotic \\
\hline Australian fig & Ficus australis & Moraceae & Exotic \\
\hline Jacaranda & Jacaranda mimosifolia & Bignoniaceae & Exotic \\
\hline Silver oak & Grevillea robusta & Proteaceae & Exotic \\
\hline Weeping bottle bush & Callistemon viminalis & Myrtaceae & Exotic \\
\hline
\end{tabular}


The tree species infested by mistletoes, the incidence of mistletoe infestation per tree species and the percentage incidence of mistletoe in host tree species in the campus are indicated in Table 2. Of the 26 tree species recorded in the campus 15 tree species, 11 indigenous and 4 exotic, were found infested by mistletoe parasitic weed. Abundance and percentage incidence varied across host tree species (Table 2). The two rare host tree species in the campus, Ziziphus mucronata and Acacia eriobola were found to be the highly preferred hosts registering the highest level (100\%) of incidence (Table 2). Acacia erubesens and Terminalia sericea, the two dominant tree species in the campus, were the other preferred tree species with a percent incidence of 78.3 and 88.2 respectively. The least preferred host tree species was Combretum apiculatum with $18.8 \%$ (Table 2). In total, 108 out of 182 of the host trees (59.3\%) in the campus were infested by mistletoe. The highest percentage incidence recorded on an exotic tree species was on Schinus molle (77.8\%) and the lowest was $25 \%$ on Jacaranda mimosifolia (Table 2).

\section{TABLE 2}

INCIDENCE OF MISTLETOE IN HOST TREE SPECIES IN RECORDED IN BOTSWANA UNIVERSITY OF Agriculture AND NATURAL RESOURCES, SEbELE CONTENT FARM CAMPUS

\begin{tabular}{|c|c|c|c|c|}
\hline Tree species & $\begin{array}{c}\text { Total number of } \\
\text { trees per species }\end{array}$ & $\begin{array}{c}\text { Number of infested } \\
\text { trees per species }\end{array}$ & $\begin{array}{c}\text { Percentage incidence } \\
\text { in infested tree species }\end{array}$ & $\begin{array}{c}\text { Incidence as percentage } \\
\text { of the total host trees }\end{array}$ \\
\hline Acacia erubesens & 37 & 29 & 78.3 & 15.9 \\
\hline Terminalia sericea & 34 & 30 & 88.2 & 16.5 \\
\hline Acacia tortilis & 25 & 12 & 48.0 & 6.6 \\
\hline Combretum apiculatum & 16 & 3 & 18.8 & 1.6 \\
\hline Melia azedarach & 12 & 3 & 25.0 & 1.6 \\
\hline Acacia mellifera & 9 & 6 & 66.7 & 3.3 \\
\hline Schinus molle & 9 & 7 & 77.8 & 3.8 \\
\hline Acacia flekii & 8 & 5 & 62.5 & 2.7 \\
\hline Jacaranda mimosifolia & 8 & 2 & 25.0 & 1.1 \\
\hline Delonix regia & 6 & 3 & 50.0 & 1.6 \\
\hline Tipuana tipu & 6 & 2 & 33.3 & 1.1 \\
\hline Sclerocarya birrea & 6 & 2 & 33.3 & 1.1 \\
\hline Combretum zeyheri & 3 & 1 & 33.3 & 0.5 \\
\hline Ziziphus mucronata & 2 & 2 & 100 & 1.1 \\
\hline Acacia eriobola & 1 & 1 & 100 & 0.5 \\
\hline
\end{tabular}

The number of mistletoe plants on a host tree varied from a maximum of 57 on Terminalia sericea to a minimum of one mistletoe per host tree (Table 3). Some of the host trees were free of the parasitic weed. Of the three Combretum zeyheri in the campus only one was infested with single mistletoe. The highest average mistletoe per tree species of $19 \%$ was recorded in Acacia eriobola (Table 3). The number of mistletoe plants on exotic tree species was generally low with the maximum average mistletoe per tree of $7 \%$ registered in Schinus molle (Table 3).

TABLE 3

LEVEL OF MISTLETOE INFESTATION IN TREE SPECIES AT BOTSWANA UNIVERSITY OF AGRICULTURE AND NATURAL RESOURCES, SEBELE CONTENT FARM CAMPUS DURING THE SURVEY OF MISTLETOE

\begin{tabular}{|c|c|c|}
\hline Tree species & Average number of mistletoe per tree & Range of mistletoe per plant \\
\hline Acacia eriobola & 19.0 & 19 \\
\hline Acacia mellifera & 14.0 & $1-48$ \\
\hline Terminalia sericea & 12.35 & $1-57$ \\
\hline Ziziphus mucronata & 7.0 & $5-9$ \\
\hline Schinus molle & 7.0 & $1-29$ \\
\hline Acacia tortilis & 6.32 & $1-32$ \\
\hline Acacia erubesens & 5.92 & $1-27$ \\
\hline Acacia flekii & 5.63 & $2-22$ \\
\hline Melia azedarach & 4.58 & $5-45$ \\
\hline Delonix regia & 1.33 & $1-4$ \\
\hline Jacaranda mimosifolia & 1.25 & $4-6$ \\
\hline Combretum apiculatum & 0.75 & $1-7$ \\
\hline Sclerocarya birrea & 0.5 & $1-2$ \\
\hline Tipuana tipu & 0.33 & $0-1$ \\
\hline Combretum zeyheri & 0.33 & $0-1$ \\
\hline
\end{tabular}


The number of trees infested and level of mistletoe infestation on indigenous tree species was very high. Acacia eriobola, Acacia mellifera and Terminalia sericea wereheavily infested with the parasitic (Figure 1) and some of trees in these species were killed due to heavy mistletoe infestation (Figure 2).

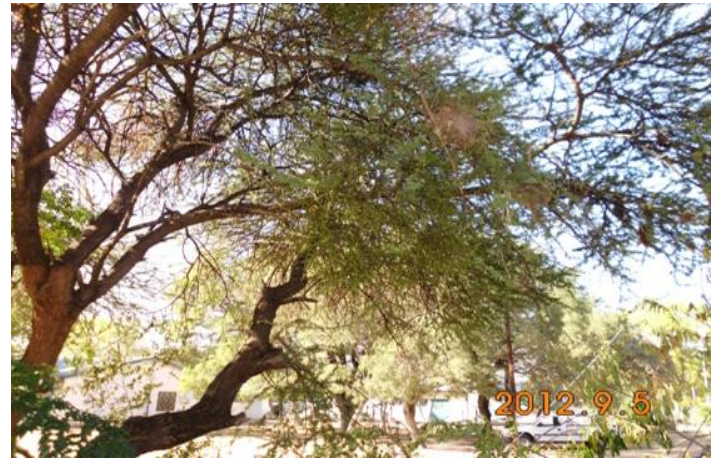

\section{Figure 1: MISTLETOE ON ACACIA TREE AT BUAN CAMPUS. FIFTEEN MISTLETOE PLANTS WERE IDENTIFIED ON THIS TREE}

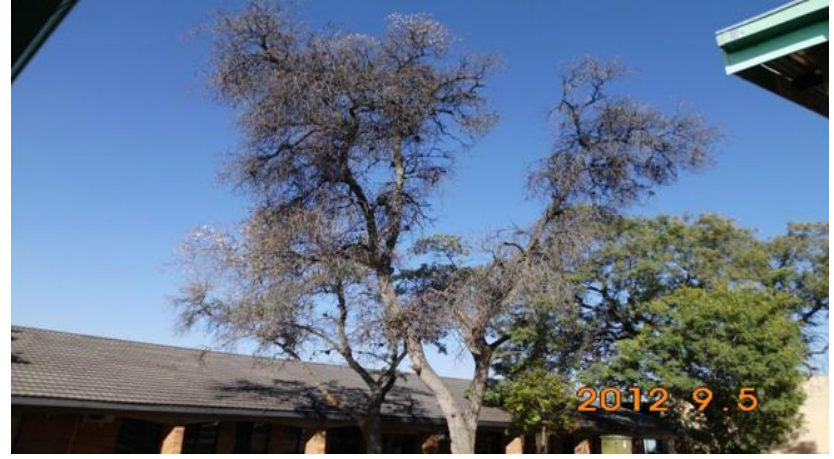

FIGURE 2: TERMINALIA SERICEA TREE KILLED BY MISTLETOE PARASITIC PLANTS AT BUAN CAMPUS

\section{DISCUSSION}

This study catalogues the diversity of plant species which can be parasitized by mistletoe and the variation in the level of mistletoe infestation among host tree species. The compilation of the current lists will serve as a baseline data for future study on host-specificity and host- parasite-disperser interaction. This will be a significant contribution to our understanding of the interactions between parasitic angiosperms and their host species that trails behind that of other plant symbiotic associations (Musselman and Press, 1995).Host plants documented were mostly dicotyledonous angiosperms with the genus Acacia contributing most of the host species recorded. Several acacia tree species were reported to be preferred hosts of mistletoe parasitic weeds (Downey, 1998). Acacia tree species are known to have a wide, big and open canopy. The branches spread out at the top with bi-pinnate leaves to form this huge canopy. As observed in this survey, almost all Acacia tree species were infested by mistletoe and had the highest intensity of mistletoe than all the other species. These results are in agreement with Lopez de Buen and Ornelas (1999) and Buen et al.(2002), who stated that the survival of mistletoe seedlings on its host species is affected by the canopy opening above the branch, and better seedling survival on host trees with more open canopies of Acacia species. Norton and Reid (1997) and Rahmad et al. (2014) also reported that host compatibility and habitat are important regulators of mistletoe abundance and distribution. Other factors such as host resistance, seedling establishment, changes in the surrounding environment and individual tree factors such as branch size, age and height, and seed predation also influence the abundance and distribution of mistletoe (Lopez de Buen and Ornelas, 1999; Buen et al., 2002). This is in line with our result that shows higher intensity of mistletoe infestation on the Acacia tree species.

Terminalia sericea was the other preferred host tree species that was highly infested by mistletoes. Some of the Terminalia sericea trees were already dying due to high intensity of mistletoe. The trees produced considerable witches broom and some of the mistletoe brooms were drying or already dried because of higher mistletoe infestation that resulted in the death of the host plant. Resources available to parasitic plant are often dependent on resources available to hosts. If a resource is limiting to parasites because it is limiting to hosts, supplementing that resource for hosts should affect parasites (Spurrier and Smith, 2005). According to Fisher (1993) water potential gradient between the host and mistletoe provides the mechanism by which water and dissolved solutes flow towards the parasite. The gradient is maintained through a combination of high parasite transpiration rates and high resistance in the hydraulic pathway between the host and parasite, especially at the haustorium interface (Whittington and Sinclair, 1988; Davidson and Pate, 1992). A significant negative relationship between mistletoe volume and host survival was also observed in this study. Tennakoon and Pate (1996) found that mistletoe infestation cause gradual death of the host branch tissue distal to the point of mistletoe attachment and increased growth of branches proximal to the mistletoe, relative to the branches supporting a similar area of host foliage. In another similar research by Ehleringer $e t$ al. (1986), mistletoe infection reported to cause declines in leaf water potential, stomatal conductance, photosynthesis and leaf nitrogen content in its host.

One of the interesting observations in this study was the absence of mistletoes in most of the exotic tree species and some indigenous trees. The host plant preference by the parasitic organisms observed in this study due to a number of factors. 
Some mistletoe species are specialized in living on different host due to frequent encounters between mistletoe seeds and commonest plants (Fadini, 2011). Mistletoe seeds in the campus may have a better and easy access to acacia and Terminalia tree species which are the dominant ones in the area dominant ones in the area (Rahmad et al., 2014). The height and canopy of tree species in these two genera may also contributed to the preference and high level of infestation observed. These are some of the tree species which usually grow tall and dense with good nesting structures and fruits so are mostly preferred by birds which are known to disperse mistletoe seeds. According to Overton (1994), tall trees could attract more seed dispersal birds, and therefore receive more mistletoe seeds.

\section{CONCLUSION}

The study identified that indigenous tree species are preferred hosts of mistletoe and carry higher level of infestation compared to exotic species. The frequency of infection and density of mistletoe in each host results from interspecific differences in growth habit and abundance. The process of colonization of a tree likely depends on visit by dispersers, mistletoe seed deposition and establishment. Although the study touched upon only two factors that impinge on parasitism frequency, it highlighted a significant aspect of the interaction between mistletoes, hosts, and avian-seed dispersers. Further detailed research on the tri-trophic interaction and the effect on the ecosystem is recommended.

\section{REFERENCES}

[1] Barlow, B.A. (1993) Biogeography of Loranthaceae and Viscaceae. Academic Press, Sydney

[2] Bekker, R.P. and De Wit, P.V. (1991). Contribution to the Soil and Vegetation Classification of Botswana, Field Document no.34 FAO/UNDP/Government. Soil Mapping and Advisory services Project.

[3] Buen,L.L., Ornelas, J. F. and Garcia-Franco, J. G. (2002). Mistletoe infection of trees located at fragmented forest edges in the cloud forests of Central Veracruz Mexico. Forest ecology and management 164: 293-302.

[4] Butin, H. (1995). Tree diseases and disorders.Oxford University Press. NY

[5] Calder, M. (1983). Mistletoes in focus: An introduction. Pages 1-18. The Biology of Mistletoes. M. Calder and P. Bernhardt, eds. Academic Press, San Diego, CA.

[6] Carnegie, A. J., Bi H., Arnold, S., Li, Y. and Binns, D.(2009). Distribution, host preference, and impact of parasitic mistletoes (Loranthaceae) in young eucalypt plantations in New South Wales, Australia. Botany Botanique.87 (1): 49-63

[7] Cooney, S. J. N. and Watson, D. M. (2008). An experimental approach to understanding the use of mistletoe as a nest substrate for birds: Nest predation. Wildlife Res. 35:65-71.

[8] Downey, P. O. (1998). An inventory of host species for each aerial mistletoe species (Loranthaceae and Viscaceae) in Australia. Cunninghamia, 5(3): 685-720.

[9] Ehleringer, J. R., Ullman, I., Lange, O. L., Farquhar, G. D., Cowan, I. R., Schulze, E.-D. and Ziegler, H. 1986. Mistletoes: A hypothesis concerning morphological and chemical avoidance of herbivory. Oecologia 70:234-237.

[10] Fadini, R.F.(2011). Non-overlap of hosts used by three congeneric and sympatric loranthaceous mistletoe species in an Amazonian Savanna:host generalization to extreme specialization. Acta Botanica Brazilica 25:337-345.

[11] Fisher, J.T. (1993). Water relations of mistletoes and their hosts. Academic Press, Sydney

[12] Gill, L. S., and Hawksworth, F. G. (1996). The mistletoes: A literature review. U.S. Dep. Agric. For. Serv. Tech. Bull. 1242.

[13] Hawksworth FG. (1977). The 6-class dwarf mistletoe rating system. USDA Forest Service, Rocky Mountain Forest and Range Experiment Station, Fort Collins, Colorado, General Technical Report RM-48, 7 pp.

[14] Hellmuth, E.O. (1998): Eco-physiological studies on plants in arid and semi-arid regions of W. Australia. IV. Comparison of the field physiology of the host Acacia grasbyiand its hemiparasiteAmyemanestor under optimal and stress conditions. Journal of Ecology 59, 351-363.

[15] Kintzios, S., and Barberaki, M. (2000). The biotechnology of Viscum album L.: Tissue culture, somatic embryogenesis, and protoplast isolation. Pages 95-99 in: Mistletoe, The Genus Viscum. A. Büssing, ed. Harwood Academic Publishers, Amsterdam, The Netherlands.

[16] Lamont, B. (1996). Mineral nutrition of mistletoes. Academic Press, Sydney

[17] Liddy, J. (1993).Dispersal of Australian mistletoes.Oxford University Press. London

[18] Lopez de Buen, L. and Ornelas J. F.(1999). Frugivorous birds, host selection and the mistletoe Psittacanthus schiedeanus, in central Veracruz, Mexico. J. Trop. Ecol. 15: 329-340.

[19] Monteiro,R.F.,Martins, R. P. and Yamamoto, K. (1992). Host specificity and seed dispersal of Psittacanthus robustus(Loranthaceae) in South-East Brazil. Journal of Tropical Ecology 8:307-314.

[20] Musselman, L.J. and Press, M.C. (1995) Introduction to parasitic plants. In M.C. Press \& J.D. Graves (Eds) Parasitic Plants, pp. 1-13 (Chapman \& Hall: Melbourne).

[21] Norton, D.A. Reid, N.(1997). Lessons in ecosystem management from management of threatened and pest Loranthaceous mistletoes in New Zealand and Australia. Conserv. Biol. 11: 759-769.

[22] Overton, J. M.(1994). Dispersal and infection in mistletoe metapopulations. J.Ecol. 82: 711-723. 
[23] Parker, C. and Riches, C. R. (1993). Parasitic weeds of the world: Biology and control. CABI International. UK

[24] Persaud, N., Joshua, W.D., Mokete, N., Pule, F. and Moroke, T.S. (1992). Report on the soil of the tillage and fertilizer sites, Department of Agricultural Research, Ministry of Agriculture, Botswana Government Printer pp 6-28.

[25] Reid N, Smith M. S. (2000). Population dynamics of an arid zone mistletoe (Amyemapreissii, Loranthaceae) and its host Acacia victoriae (Mimosaceae). Australian Journal of Botany. 2000. 48 (1): 45-58

[26] Reid N, Zhaogui Y, Jim F (1994). Impact of mistletoes (Amyemamiquelii) on host (Eucalyptus blackelyii and Eucalyptus mellidora) survival and growth in temperate Australia.Forest ecology management 70: 55-65

[27] Spurrier, S.E and Smith, K.G. (2005). Watering blue palo verde (Cercidium floridum) affects berry maturation of parasitic desert mistletoe (Phoradendron californicum) during an extreme drought in the Mojave Desert. University of Arkansas, Fayetteville, AR 72701, USA

[28] Tennakoon, K. U. and Pate, J. S. (1996). Effects of parasitism by a mistletoe on the structure and functioning of branches of its host. Plant Cell Environ. 19:517-528. 